\title{
Treatment of a severe distal forelimb wound presenting with extensive laceration and distal interphalangeal joint luxation in a donkey
}

\author{
Laurent Brogniez', M. Thomas Launois', Roland A. R. Perrin', Lena Horn' ', Peter D. Clegg ${ }^{2}$, Richard Coomer ${ }^{3}$, Annick Gabriel', Sandri- \\ ne Mesnil5, Bianca Carstanjen ${ }^{6}$, Francis Desbrosse' ${ }^{1}$, Nathalie Kirschvink' and Jean Michel E. F Vandeweerd', 7
}

Clinique Equine Desbrosse, St. Lambert des Bois, France', Department of Veterinary Clinical Science and Animal Husbandry, The University of Liverpool, South Wirral ${ }^{2}$, Cotts Equine Hospital, Narberth, Pembrokeshire, UK33, Département de morphologie et pathologie, Faculté de Médecine Vétérinaire de I'Université de Liège, Liège, Belgium ${ }^{4}$, Clinique de Genainville, Genainville, France ${ }^{5}$, Equine Clinic, Faculty of Veterinary Medicine, Freie Universität Berlin, Germany ${ }^{6}$ and Integrated Veterinary Research Unit (IVRU), Namur Research Institute for Life Sciences (NARILIS), Department of Veterinary Medicine, Faculty of Sciences, University of Namur, Namur, Belgium

\begin{abstract}
Summary
This report describes the clinical presentation, management and outcome in a donkey with severe distal limb laceration and distal interphalangeal (DIP) luxation. Soft tissue damage was extensive leaving flexor tendons and palmar conjunctive tissue and skin as the only support structures to connect the distal phalanx and hoof to the rest of the distal limb. Arteriography was performed under general anesthesia to assess vascular supply to the foot. The palmar digital artery and its major branches to the foot were identified on the digital angiograms. The arcus terminalis, ramus palmaris arcus terminalis and ramus marginalis solearis which vascularise the sole were visible. Surgical exploration of the wound confirmed the complete transection of the DIP joint capsule, the DIP collateral ligaments and the distal sesamoidean ligament. The perioplic corium and coronary corium were separated from the laminar corium and remained attached to the skin of the pastern. Synovial lavage and regional antibiotherapy were performed. After surgical debridment, the perioplic corium and coronary corium were repositioned in their groove. The skin was sutured to the horn with stainless steel wire, polydioxanone sutures and stainless steel staples. A half limb cast was applied for protection during recovery from anaesthesia and was bivalved after 48 hours to be used as a protective and support device. Complications included an episode of laminitis of the controlateral limb and hyperlipaemia. Twelve months following surgery, the donkey was living normally in pasture, though being lame at walk. This case highlights several simple techniques that can be used in severe pastern wounds.
\end{abstract}

Keywords: donkey / distal interphalangeal joint / luxation / laceration / arteriography / computed tomography / traumatology

\section{Behandlung einer schweren Verletzung der distalen Vorderzehe mit Hufgelenksluxation bei einem Esel}

Die Huf- und Fesselregion ist aufgrund ihrer distalen Lage an der Extremität besonders anfällig für Verletzungen. Traumatisch bedingte, partielle Hufwandabrisse können vorkommen, allerdings wurde ein vollständiger Abriss der Hufwand selten beschrieben. Von Hufgelenkssubluxationen nach schweren Verletzungen des gemeinsamen Zehenstreckers und der dorsalen Kapselanlagen des Hufgelenks wurde berichtet. Aufgrund des Auftretens degenerativer Gelenkerkrankungen ist die Prognose restitutio ad integrum vorsichtig zu stellen. Zudem haben traumatische Wunden unter Beteiligung synovialer Strukturen der Gliedmaßen eine sehr schlechte Prognose. Schwere oder chronische Infektionen die diese Verletzungen begleiten sind aufgrund von Gefäßverschlüssen, Ischämien und Gewebsnekrosen schwer zu behandeln. Um das Hufgelenk zu stabilisieren kann bei Abwesenheit von Infektionen eine distale Arthrodese durchgeführt werden. Dieser Bericht beschreibt den klinischen Fall eines Esels mit einer, durch eine Schnittwunde hervorgerufenen, schweren distalen Gliedmaßenverletzung, samt Luxation des Hufgelenks, Beschädigung des Hufs und Abriss der Hufwand, sowie deren Therapie und ihr erfolgreiches Ergebnis. Es werden ebenfalls einige einfache Behandlungsmethoden die in solch einem Fall angewandt werden können beschrieben. In diesem Fall lagen umfangreiche Weichteilschäden vor. Der Huf und das Hufgelenk waren lediglich durch die Beugesehen, das palmare Bindegewebe und die Haut mit der distalen Gliedmaße verbunden. Um die Gefäßversorgung des Hufs zu beurteilen wurde unter Vollnarkose eine Arteriographie durchgeführt. Das Kontrastmittel wurde in die, an der medialen Seite des Fesselgelenks vorsichtig freipräparierte, A. digitalis medialis injiziert. Anhand der digitalen Angiographie konnten die A. digitalis palmaris und ihre wichtigsten Abzweigungen im Huf identifiziert werden. Der arcus terminalis, Ramus palmaris arcus terminalis und Ramus marginalis solearis, welche die alleinige Blutversorgung des Hufs sicherstellen, waren sichtbar. Die Untersuchung der Wunde unter chirurgischen Bedingungen bestätigte die vollständige Durchtrennung der Hufgelenkskapsel, sowie der Seitenbänder und des ligamentum sesamoidale distale. Die Saumlederhaut und Kronlederhaut wurden von der Wandlederhaut getrennt und blieben mit der Haut der Fessel verbunden. Die synovialen Einrichtungen wurden mit reichlich Ringer-Laktatlösung gespühlt und es wurde eine regionale Antibiotikatherapie mit Gentamycin durchgeführt. Nach dem chirurgischen debridment wurden die Saum- und Kronlederhaut in ihre ursprüngliche Lage zurückversetzt. Die Haut wurde mit Hilfe von Edelstahl-Draht, Polydioxanon Nahtmaterial und Klammern aus Edelstahl mit dem Huf verbunden. Zum Schutz beim Erwachen aus der Narkose wurde ein cast angebracht. Dieser wurde am nächsten Tag in zwei Hälften geteilt und weiterhin als als Schiene zum Schutz und zur Stütze der Gliedmaße verwendet. Als postoperative Komplikationen traten Hufrehe der kontralateralen Extremität, Anorexie und Hyperlipidämie auf. Zur Behandlung der Hufrehe wurde zweimal am Tag lokale Kryotherapie (hyperbares CO2) auf dem kontralateralen Kronsaum durchgeführt und nicht-steroidale Antiphlogistika verabreicht. Der Esel wurde mit frischem Gras und Hafer versorgt. Die Schmerzhaftigkeit, der Appetit und die Triglycerid-Konzentration verbesserten sich ab dem 21. Tag nach dem Eingriff. 1 Monat nach der Operation wurde der Esel entlassen. Zwölf Monate nach dem Eingriff lebte der Esel, trotz einer noch bestehenden Lahmheit, auf der Weide. Dieser Fall unterstreicht, dass die konsequente Therapie schwerster Verletzungen, einhergehend mit einer Luxation des Hufgelenks, im distalen Gliedmaßenbereich erfolgreich sein kann. Zudem werden mehrere einfache Techniken beschrieben die hierbei verwendet werden können. Die synoviale Lavage, die Vernähung des Kronsaums und die Immobilisierung der betroffenen Gliedmaße durch Anbringen eines Casts werden als verbindliche Maßnahmen angesehen.

Schüsselwörter: Hufwandabriss / Schnittwunde / Hufgelenk / Arteriographie / Esel / Traumatologie 


\section{Introduction}

Foot and pastern regions are particularly susceptible to trauma because of their distal location on the limb. Lacerations and avulsion injuries are often caused by barbed wire, kikking at or stepping on sharp objects, or as the result of the foot becoming entrapped (Stashak 1989). Traumatic hoof wall avulsion is not uncommon though complete full thikkness hoof wall avulsion is a rare condition in horses (de Gresti et al. 2008). Distal interphalangeal (DIP) joint subluxation following severe laceration of the common digital extensor tendon and the dorsal capsular attachments of the DIP joint has been reported. The prognosis for return to usual activity is poor as degenerative joint disease will occur and DIP arthrodesis may sometimes be performed to stabilise the joint as a salvage procedure if infection is not present (Reeves et al. 1989).

There is also general consensus in the veterinary literature that the keys to successful treatment of horses with septic synovitis are early recognition and prompt treatment (Nixon 1990, Chan et al. 2000, Fraser and Bladon 2004, Wright et al. 2003). In a recent retrospective study, the outcome was considered successful (survival without residual lameness) in 109 of 150 horses (72.7\%) with contaminated and infected synovial cavities (Pille et al. 2009). Severe or chronic infections are more difficult to treat because of the vascular thrombosis, ischaemia and tissue necrosis that accompany these injuries (Janicek et al. 2005).

This report describes the clinical presentation, management and outcome in a case of severe distal limb laceration with DIP luxation.

\section{Case details}

History

A 19-year-old stallion donkey weighing $280 \mathrm{~kg}$ was referred to our clinic for a transverse laceration of the coronary band of the right forelimb. The donkey was living free in the owner's factory and had been hit by a lorry four hours before. The donkey also had a history of recurrent laminitis.

\section{Clinical findings}

During initial examination at the hospital the donkey could bear weight and was grade 4/5 lame at the walk. After bandage removal a 270 degree horizontal laceration was noted starting from the medial heel bulb and coursing cranially to the dorsal recess of the DIP joint, then laterally to the lateral heel bulb. Soft tissue swelling was apparent proximal to the coronary band. Instability was detected at manipulation of the distal limb and flexion revealed a complete luxation of the DIP joint with transection of its capsule, its collateral ligaments and the distal sesamoidean ligament. The foot remained attached to the limb by the flexor tendons, conjunctive tissue and palmar skin. A flexed lateromedial radiograph was obtained (Figure 1) which showed complete disarticulation of the DIP joint with the distal sesamoid bone remained attached to the middle phalanx. A half-limb bandage was applied to protect and support the distal limb and the donkey was prepared for general anaesthesia and surgery.

\section{Surgery}

Preoperatively, cefquinome (Cobactan 4,5\%, Intervet SA, Beaucouze, France, $1.0 \mathrm{mg} / \mathrm{kg}$, IV), gentamicin (G4, Virbac, Paris, France, $6.6 \mathrm{mg} / \mathrm{kg}, \mathrm{IV}$ ) and flunixin (Finadyne, Schering-Plough, Levallois Perret, France, $1.1 \mathrm{mg} / \mathrm{kg}$, IV) were administered. Anaesthesia was induced with xylazine (Rompun $2 \%$, Bayer, Puteaux, France, $1.1 \mathrm{mg} / \mathrm{kg}$, IV), ketamine

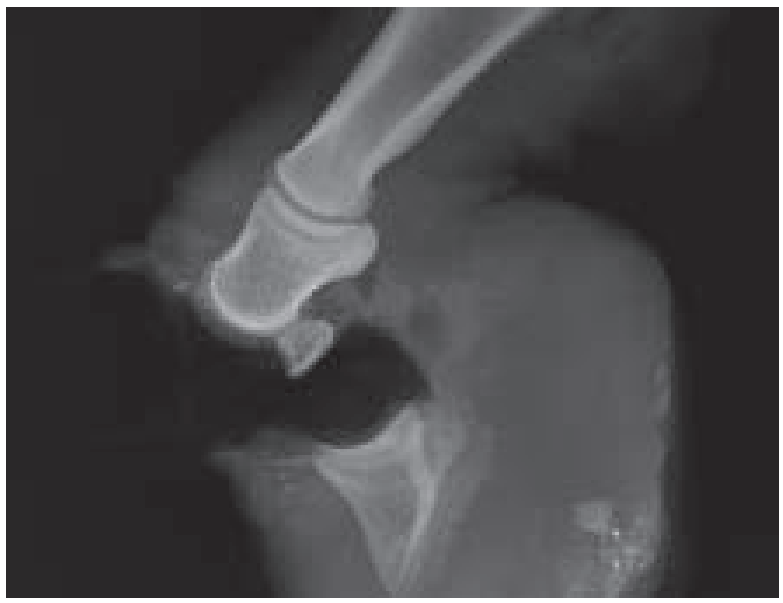

Fig. 1 Flexed horizontal latero-medial radiograph showing complete disarticulation of the DIP joint with the distal sesamoid bone remained attached to the middle phalanx.

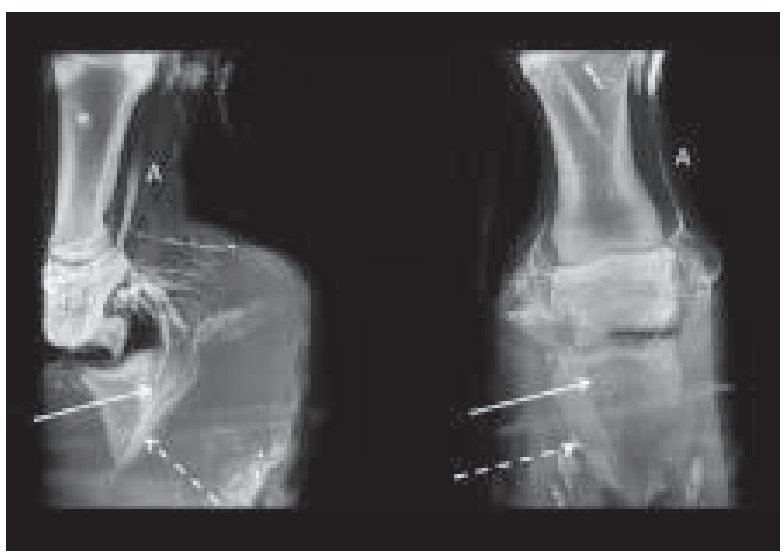

Fig. 2 Digital angiogram of the artery digitalis palmaris communis II (A) and its major branches to the equine foot, including the arcus terminalis (plain arrow) and the ramus marginalis solearis (dotted arrow).

(Imalgene, Merial, Lyon, France, $2.2 \mathrm{mg} / \mathrm{kg}, \mathrm{IV}$ ), and diazepam (Valium, Roche, Paris, France, $0.05 \mathrm{mg} / \mathrm{kg}, \mathrm{IV}$ ). After intubation, anaesthesia was maintained with oxygen and isoflourane (AErrane, Baxter SAS, Maurepas, France). The donkey was placed in right lateral recumbency, i.e. with the affected limb lower-most. Hair was clipped from the coronary band to the mid-radius. The skin was aseptically prepared. A high four point nerve block was performed and a tourniquet was applied immediately proximal to the fetlock.

A $2 \mathrm{~cm}$ skin incision was made along the digital neurovascular bundle on the medial aspect of the fetlock and the digital 
artery was bluntly dissected. The vessel was gently isolated and elevated with mosquito forceps. Then a $0.6 \mathrm{~mm} 23 \mathrm{G}$ butterfly catheter (Venoflux, Vygon, Ecoven, France) was inserted into the artery and $10 \mathrm{mLs}$ of $32 \%$ meglumine and sodium ioxaglate (Hexabrix 320, Guerbet, Roissy, France) were injected. Medio-lateral and dorso-palmar radiograph of the digit were made immediately after the injection. The palmar digital artery and its major branches to the foot were identified on the digital angiograms. The arcus terminalis, ramus palmaris arcus terminalis and ramus marginalis solearis which vascularise the sole were visible and contained contrast medium (Figure 2).

Gentamicin (500 mgs) diluted in $50 \mathrm{mLs} 0.9 \% \mathrm{NaCl}$ was injected intra-arterially through the butterfly catheter. Then the wound was flushed with 6 litres ringer-lactate (Ringer Lactate Vetoflex, Bioluz, Saint Jean De Luz, France) administered with a large-bore infusion set, ensuring generous lavage of the exposed DIP joint and navicular bursa. Exploration of the wound confirmed the complete transection of the DIP joint capsule, the DIP collateral ligaments and the distal sesamoidean ligament. There was no major damage to the collateral cartilages. The perioplic corium and coronary corium were separated from the laminar corium and remained attached to the skin of the pastern (Figure 3). Gentle debridement of the margins of the skin, the subcutaneous tissue and the sectioned ligaments was carried out. A sponge impregnated with gentamicin (Collatamp, Eusa pharma, Lyon, France) was placed in the synovial cavity of the DIP joint and the luxation reduced. The perioplic corium and coronary corium were repositioned in their groove. Three 4-metric stainless steel sutures (Steel Wire Monofilament, Ethicon, Issy les Moulineaux, France) and eight 4-metric polydioxanone sutures (PDS II, Johnson\&Johnson, Paris, France) mounted on cutting needles were placed in a horizontal interrupted mattress pattern through the proximal hoof wall and the edge of the skin of the pastern. Stainless steel staples (Autosuture Royal, Tyco, Norwalk, USA) were applied to join the skin and the horn along the coronary band (Figure 4). After surgery, a half limb cast was applied for protection during recovery from anaesthesia.

\section{Clinical follow-up}

The cast was bi-valved after 48 hours and bandages under the cast were changed. Phenylbutazone (Phenylarthrite Injectable, Vetoquinol, Lure, France, $1.1 \mathrm{mg} / \mathrm{kg}$, IV) was administered every 12 hours. The initial antimicrobial regimen was continued with cefquinome $(1.0 \mathrm{mg} / \mathrm{kg}, \mathrm{IV}, \mathrm{q} .24 \mathrm{~h})$ and gentamicin $(6.6 \mathrm{mg} / \mathrm{kg}, \mathrm{IV}, \mathrm{q} .24 \mathrm{~h})$. The donkey could bear weight on both limbs and had a good appetite for seven days. Gentamicine was stopped and oral phenylbutazone (Equipalazone, Dechra Veterinary Products, Suresnes, France, $1.1 \mathrm{mg} / \mathrm{kg}$, PO) was instituted. At the first bandage change at 7 days, the wound appeared clean with very little discharge. However, pain of the controlateral limb was evident due to laminitis of the contralateral limb, associated with anorexia and hyperlipaemia. Parenteral antibiotics were discontinued and replaced by oral trimetoprim-sulfamethoxypyridazine (Avemix, Vetoquinol, Lure, France, $20 \mathrm{mg} / \mathrm{kg}, \mathrm{PO}$ ) q.12 h. Cryotherapy (hyperbaric $\mathrm{CO}_{2}$ ) was performed on the controlateral foot and coronary band twice a day (Desbrosse 2003). Fresh grass and oats were supplied. The donkey also reduced its water intake. Urea and creatinine concentrations were abnormally increased two weeks after surgery (urea $1.18 \mathrm{~g} / \mathrm{l}$, reference range 0.2 to $0.6 \mathrm{~g} / \mathrm{l}$; creatinine $34.8 \mathrm{mg} / \mathrm{l}$, reference range 9.0 to $21.0 \mathrm{mg} / \mathrm{l})$. Intravenous perfusion of 20 litres lactated Ringer per day was performed for three days. Pain, appetite and triglycerides concentration improved at day 21 . The donkey was discharged one month after the surgery. The owner was instructed to administer trimetoprim-sulfamethoxypyridazine $(20 \mathrm{mg} / \mathrm{kg}, \mathrm{PO})$ twice a day and oral phenylbutazone $(1.1 \mathrm{mg} / \mathrm{kg}, \mathrm{PO})$ once a day for one week, to open the bivalved cast for a bandage change once a week, and to keep the donkey in a stable.

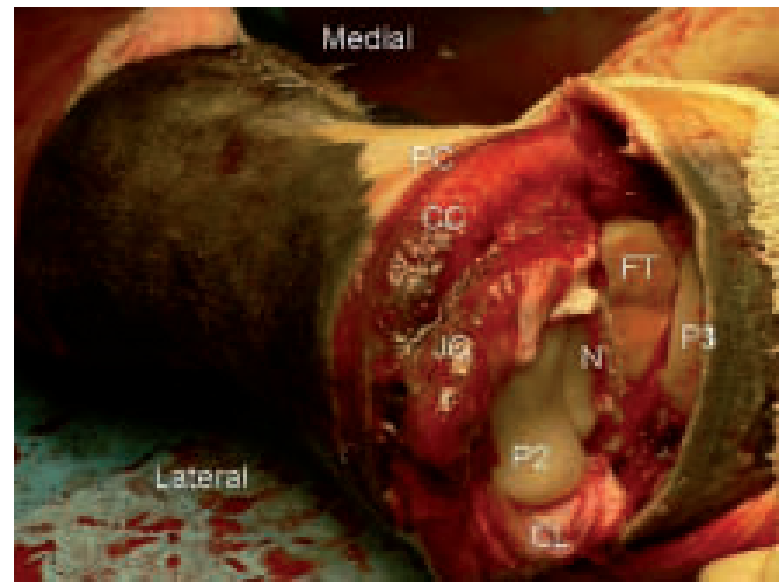

Fig. 3 Anatomical structures that could be visualised at surgery were the perioplic corium (PC), coronary corium (CC), DIP joint capsule (JC), middle phalanx (P2), distal sesamoid bone (N), collateral ligaments $(\mathrm{CL})$, flexor tendons (FT) and distal phalanx (P3)

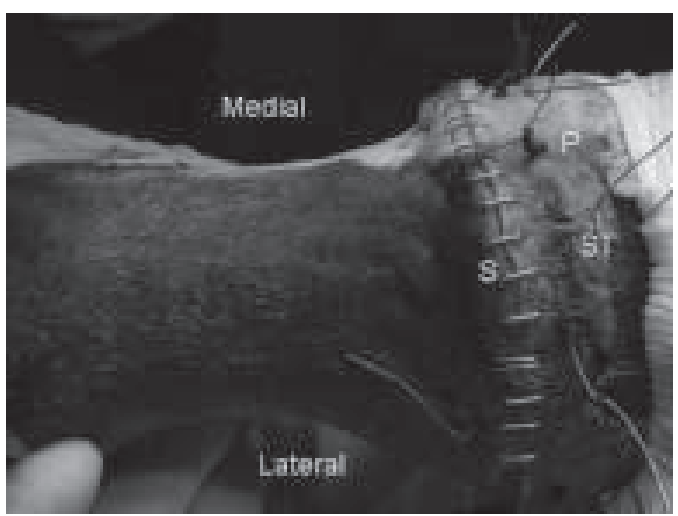

Fig. 4 Surgical site after suture with stainless steel wires (ST), polydioxanone (P) and staples (S)

The donkey remained comfortable afterwards. The staples and sutures were removed two months after the surgery by the referring veterinarian. No discharge was present. The donkey was comfortable at walk. For cost issues, no radiographies could be performed after discharge from our hospital. Six and twelve months after the surgery the referring veterinary surgeon was contacted by telephone. The donkey was reported to be living normally, though being still lame 2 on a scale of 5 .

\section{Discussion}

In deep lacerations of the coronary band vital structures are usually involved including: (1) digital vessels and nerves; (2) 
synovial structures i.e. digital tendon sheath, proximal and distal interphalangeal joints and navicular bursa; (3) flexor tendons, common digital extensor tendon and collateral ligaments; (4) collateral cartilages of the distal phalanx. Those injuries can also be associated with fractures of the distal and/or middle phalanx, and luxation of the DIP joint. In this case, soft tissue damage was very extensive leaving flexor tendons and palmar conjunctive tissue and skin as the only support structures to connect the distal phalanx and hoof to the rest of the distal limb. In addition, the DIP joint and navicular bursa were lacerated and contaminated. Furthermore, it was not evident that blood supply to the distal phalanx was preserved. Further diagnostic techniques were therefore necessary to document the lesions.

Angiography is a radiographic technique that enhances blood vessels by use of a radiopaque solution, administered intravenously or intra-arterially. Peripheral angiography has been used to define normal digital vascular anatomy in horses (Ackerman et al. 1975) and to quantify the diameter of these vessels (Rosenstein et al. 2000). Arteriography has also been used to study the arterial supply of the navicular bones of horses with clinical and/or radiographic signs of navicular disease (Rijkenhuizen et al. 1989). Blood supply to the laminar corium (dermis) in ponies with onset of acute laminitis has been evaluated (Coffman et al. 1970, Pollitt and Molyneux 1990, Redden 1993, Weiss et al. 1994). In cases of laminitis and traumatic avulsion, a venogram is recommended to assess the state of vascularisation (de Gresti et al. 2008) as a lack of blood supply to the digit could affect the healing process interfering with the re-growth of the new hoof (Parks 1999). Scott et al. (1976) showed that vascular supply of the equine forelimb was only partially disrupted by ligation of the medial palmar and lateral palmar digital arteries and that existing collaterals or newly formed collaterals, or both, were sufficient to maintain limb viability. Our report illustrates the use of arteriography to assess vascular supply to the foot after extensive soft tissues disruption in the pastern region. In this case, the vasculature could be identified and contrast medium was present in the arcus terminalis, ramus palmaris arcus terminalis and ramus marginalis solearis. As reported by Rosenstein et al. (2000), the dorso-palmar projection was more useful for evaluation of the terminal arch and solar branches, but a latero-medial view was also necessary for a thorough examination of the foot. The presence of blood supply in the solar region was the main decisional criteria to proceed with the surgical intervention. The technique of arteriography was easy, though digital arteries were not palpable owing to the hypoperfusion of the distal limb associated with general anaesthesia. However the vessels were easily identified after surgical dissection along the neurovascular bundle.

In contaminated synovial cavities the objectives of surgical treatment are the removal of foreign material, debridement of contaminated and devitalised tissue, elimination of microorganisms, removal of destructive enzymes and free radicals, promotion of tissue healing and restoration of a normal synovial environment (Wright et al. 2003). Lavage of the synovial cavity is the treatment of choice. Flushing the joint with sterile balanced solution would decrease bacterial contaminants and remove the mediators and by-products of inflammation. Antibiotic therapy is also a major component in the treatment of synovial cavity sepsis (Bertone et al. 1987). Antibiotics can be administered by direct administration into the cavity by periodic injection or by continuous lavage delivery system, by regional intravenous or interosseus perfusion, by impregnated polymethylacrylate beads or biodegradable hydroxyapatite cement or dextran gel, by antibiotic impregnated cellulose sponge, and systemically. Vascular injury or thrombosis limits the delivery of systematically administered antibiotics and regional limb perfusion should be considered to deliver an antimicrobial under pressure to a selected region of the $\operatorname{limb}$ (Janicek et al. 2005). In this case, the wound was debrided, thoroughly flushed during the whole procedure and antibiotics were administered intra-operatively by regional limb perfusion. Furthermore, gentamicin was also delivered locally by the impregnated sponge left in situ. Systemic broad spectrum antibiotics were maintained for 5 weeks. The absence of sepsis post-operatively were most likely attributable to our aggressive therapy and also prompt intervention within six hours of the injury. However, it is very likely that the horse developed osteoarthritis, a common complication of such injuries (Reeves et al. 1989). The lack of control radiographs a few months after surgery constitutes a weakness in this report. Unfortunately they were impossible to obtain for financial reasons. Our results should be taken at face value; we make no claim of absence of osteoarthritis and we only suggest that those animals with such severe wounds of the distal limb do not necessarily have to be euthanized.

Certain donkeys, subjected to a stressor such as dietary change or pain, become depressed and anorexic over a period of 2-10 days. They develop a syndrome of hyperlipaemia which leads to systemic organ failure (Fowler 1989). Treatment includes control of pain, supply of a wide variety of foods (grass, haylage, hay, carrots), administration of Hartmann solution and isotonic multi-vitamin/mineral/amino acid preparations. High dose insulin therapy is also advocated by some authors (Waitt and Cebra 2009). In the current case, aggressive treatment was instituted at first clinical signs and well before the reported critical lipid concentrations of 800 $\mathrm{mg} / 100 \mathrm{ml}$ was reached (Fowler 1989). This may explain the successful outcome.

In lacerations of the pastern, the combination of suturing and casting usually provides the best functional results in our experience. Alignment and apposition of the coronary band is most important to the outcome (Stashak 1989). In a retrospective study, wounds involving the pastern and foot that were treated with a phalangeal cast carried a good prognosis for soundness and cosmetic healing (Ketzner et al. 2009). When the DIP joint is involved, arthrodesis may sometimes be performed to stabilize the joint as a salvage procedure if infection is not present (Reeves et al. 1989). In this case, stainless steel and polydioxanone sutures were placed directly through the skin of the coronary band, the coronary corium and the thin hoof wall just below the defect in the coronet. The staples and sutures were removed after a long period of two months. There was no real rationale in this delay except the subjective feeling of the referring veterinarian to provide further support to a reconstruction that appeared initially extensive and very unstable. A half limb cast was placed for recovery and cut the day after surgery for bandage change. It was opened bivalve and used to protect the foot in the first three weeks. The opening of the cast 48 hours after surgery is questionable. It may have been better to leave the cast for 
a longer period to provide better immobilisation. However it was also considered essential to assess the wound accurately for discharge and sepsis as soon as possible.

This case report shows that prompt and aggressive treatment can be a life-saving measure in severe distal limb wounds with DIP joint luxation. Synovial lavage, suturing of the coronary band and immobilisation by casting are considered mandatory.

\section{References}

Ackerman N., Garner H. E., Coffman J. R. and Clement J. W. (1975) Angiographic appearance of the normal equine foot and alterations in chronic laminitis. J. Am. Vet. Med. Assoc. 166, 58-62

Bertone A. L., Mcllwraith C. W., Powers B. E., Stashak T. S., Aanes W. A. and Turner A. S. (1986) Subchondral osseous cystic lesions of the elbow of horses: conservative versus surgical treatment. J. Am. Vet. Med. Assoc. 189, 540-546

Chan C. C., Murphy H. and Munroe G. A. (2000) Treatment of chronic digital septic tenosynovitis in 12 horses by modified open annular ligament desmotomy and passive open drainage. Vet. Rec. 147, 388-393

Coffman J. R., Johnson J. H., Guffy M. M. and Finocchio E. J. (1970) Hoof circulation in equine laminitis. J. Am. Vet. Med. Assoc. 156, 76-83

Desbrosse F. (2003) Les propriétés analgésiques de la cryothérapie au $\mathrm{CO}_{2}$ hyperbare. Pratique Vétérinaire Equine. 35, 97-105

Fraser B. S. and Bladon B. M. (2004) Tenoscopic surgery for treatment of lacerations of the digital flexor tendon sheath. Equine Vet. J. $36,528-531$

Fowler J. N. (1989) Medical. In: The professional handbook of the donkey. The Donkey Sanctuary (ed), 2 nd edition, Sovereign Printing Group, England, pp. 108-109

Gibson K. T., Mcllwraith C. W., Turner A. S., Stashak T. S., Aanes W. A. and Trotter G. W. (1989) Open joint injuries in horses: 58 cases (1980-1986). J. Am. Vet. Med. Assoc. 194, 398-404

Janicek J. C., Dabareiner R. M., Honnas C. M. and Crabill M. A. (2005) Heel bulb lacerations in horses: 101 cases (1988-1994). J. Am. Vet. Med. Assoc. 226, 418-23

Ketzner K. M., Stewart A. A., Byron C. R., Stewart M., Gaughan E. M., Vanharreveld P. D. and Lillich J. D. (2009) Wounds of the pastern and foot region managed with phalangeal casts: 50 cases in 49 horses (1995-2006). Aust. Vet. J. 87, 363-368

Nixon A. J. (1990) Septic tenosynovitis. In: White NA, Moore JN, eds. Current practice of equine surgery. Philadelphia: JB Lippincott Co, pp. $451-455$
Parks A. H. (1999) Equine foot wounds: general principles of healing and treatment. Proc. Am. Assoc. Equine Pract. 80, 180-187

Pille F., Martens A., Oosterlinck M., Dumoulin M., Dewulf J. and Gasthuys F. (2009). A retrospective study on 195 horses with contaminated and infected synovial cavities. Vlaams Dierg. Tijdsch. 78, 97-104

Pollitt C. C. and Molyneux G. S. (1990) A scanning electron microscopical study of the dermal microcirculation of the equine foot. Equine Vet. J. 22, 79-87

Redden R. F. (1993) The use of venograms as a diagnostic tool. Proceedings of the 7th Bluegrass Laminitis Symposium. 1-6

Rijkenhuizen A. B., Németh F., Dik K. J. and Goedegebuure S. A. (1989) The arterial supply of the navicular bone in adult horses with navicular disease. Equine Vet J. 6, 418-424

Rosenstein D. S., Bowker R. M. and Bartlett P. C. (2000) Digital angiography of the feet of horses. Am. J. Vet. Res. 61, 255-259

Scott E. A., Thrall D. E. and Sandler G. A. (1976) Angiography of equine metacarpus and phalanges: alterations with medial palmar artery and medial palmar digital artery ligation. Am J Vet Res. 37, 869-873

Stashak T. S. (1989) Management of lacerations and avulsion injuries of the foot and pastern region and hoof wall cracks. Vet. Clin. North Am. Equine Pract. 5, 195-220

Taylor T. S. and Vaughan J. T. (1980) Effects of denervation of the digit of the horse. J. Am. Vet. Med. Assoc. 177, 1033-1039

Weiss D. J., Geor R. J., Johnston G. and Trent A. M. (1994) Microvascular thrombosis associated with onset of acute laminitis in ponies. Am. J. Vet. Res. 55, 606-612

Waitt L. H. and Cebra C. K. (2009) Characterization of hypertriglyceridemia and response to treatment with insulin in horses, ponies, and donkeys: 44 cases (1995-2005). J. Am. Vet. Med. Assoc. 234, 915-919

Wright I. M., Smith M. R., Humphrey D. J., Eaton-Evans T. C. and Hillyer M. H. (2003) Endoscopic surgery in the treatment of contaminated and infected synovial cavities. Equine Vet. J. 35, 613-619

Jean Michel E. F. Vandeweerd

Integrated Veterinary Research Unit (IVRU)

Department of Veterinary Medicine

Faculty of Sciences

University of Namur

Rue de Bruxelles 61

5000 Namur

Belgium

jean-michel.vandeweerd@fundp.ac.be 